\title{
Settlement of Policy Regulation Dispute Through Mediation
}

\author{
$\operatorname{Rasji}^{1 *}$ \\ ${ }^{1}$ Lecturer at the Faculty of Law, Universitas Tarumanagara, West Jakarta, Indonesia. \\ *Corresponding author, Email: rasji@fh.untar.ac.id
}

\begin{abstract}
Policy rules are regulations issued by the government based on discretionary authority. The aim is to provide a legal basis for the implementation of government tasks because statutory regulations do not regulate them. As a matter of fact, many policy regulations contradict the higher laws and regulations, which may inflict harm to the society. As a result, a problem arises in the dispute of policy regulations between the people whose rights are impaired by policy regulations and policy-making officials. Public wants the policy rules to be cancelled, corrected or revoked while the policy-making officials keep them effective. Until now, this problem has not yet been legalized and no institution has been authorized to rule on it either. Law Number 30 of 1999 provides a possible model for resolving disputes outside the court through mediation. Mediation is a model of dispute resolution by parties assisted by mediator as a neutral third party. How is a regulation policy dispute settled by means of mediation? A mediation settlement model can be applied to dispute policy regulation settlement. Public and policy-making officials agreed on appointing a mediator who then invite the disputing parties to resolve their problem with a mutual agreement. This collective agreement is set forth therein a peace deed signed by both parties and the mediator.
\end{abstract}

Keywords: Mediation, Dispute, Marriage

\section{INTRODUCTION}

Indonesia is a state of law. One feature of which is a government that is based on laws. For this reason, the legislature has established a written law called a statutory regulation, as regulated in Law Number 12 of 2011 concerning the Formation of Statutory Regulations. In practice, the government has also formed policy regulations, so that in Indonesia two types of regulations have emerged, namely legislation and policy regulations. The purpose of forming policy regulations is to provide a legal basis for the implementation of government tasks because statutory regulations do not regulate them.

Policy rules must be in harmony with statutory regulations. In fact, many existing policy regulations contradict the laws and regulations which inflict loss upon society's rights. An example is the Circular of the Minister of State for Administrative Reform and Bureaucratic Reform Number 05 of 2010 concerning Data Collection of Honorary Workers Working in Government Environments contradicts Government Regulation Number 48 of 2005 concerning Appointment of Temporary Employees to Civil Servant Candidates in conjunction with Government Regulation Number 43 of 2007 on Amendment to Government Regulation Number 48 of 2005 concerning Appointment of Honorary Workers to Become Prospective Civil Servants [1]. As a result of this circular a community member named $\mathrm{Abu}$ Tholeb lost his right to be appointed as a prospective civil servant.

The example above shows the emergence of the issue of disputes over policy regulations between people whose rights have been impaired by policy regulations and policy-making officials. Until now, this problem has not yet been legalized and the institutions authorized to solve it. Law Number 30 of 1999 provides a possible model for resolving disputes outside the court through mediation. How to settle regulation policies dispute through mediation is an actual and urgent issue to resolve. 


\section{DISCUSSION}

\section{Policy regulations as objects of mediation}

The term policy regulation is a translation Dutch terms beleidregel[2] or policy rule (English) [3], pseudowetgeving [4], and speigelrecht (Netherlands) [5], or. J. Mannoury defines policy rules as speigelrecht (mirror law) [6]. J. Van Der Hovven views policy regulations as pseudowetgeving (pseudo-legislation) because they have the characteristics of a legislation but their formation is based on discretionary authority instead of statutory authority [7]. According to Philipus M. Hadjon, policy regulations were created by government officials as a consequence of the adoption of the principle of welfare state law by Indonesia [8]. Policy rules have the nature of regulating [9], so that they are classified into generally [10] accepted regulations that are used as guidelines or legal basis for government officials in implementing laws [11].

Policy regulations dispute with statutory regulations is legal norms dispute that commonly happen. According to legal theory, the resolution of regulatory disputes is carried out using a test rights mechanism (toetsingrecht [12] or review [13]). Until now, Indonesia's positive law has not yet regulated the mechanism and institution authorized torule out the issue. Law no. 30 of 1999 has opened a door for dispute resolution by means of mediation. However, the law does not provide a solution to the settlement of policy disputes because Article 5 stipulates that disputes which can be resolved by means of mediation are those occuring in the field of trade, rights which are fully controlled by the disputing parties, and disputes that can be reconciled.

In 2019 the government issued Regulation of the Minister of Law and Human Rights Number 2 of 2019 with a purpose of settling regulatory disputes through mediation. These regulations are applicable to fixing a disharmony of laws and regulations but not to resolving disputes over policy regulations. In state of law, policy regulations that conflict with statutory regulations must be legally accounted for. Considering that policy regulations have the same characteristics as laws and regulations, a resolution of policy regulation dispute may adopt a solution to the disharmony of laws and regulations that is by means of mediation. Thus a dispute over policy regulation is an object of mediation.

\section{The basis and mediator of resolution over policy regulation dispute}

Policy regulations are rules made by the government in accordance with their own free will [14]. This regulation is maintained in the context of exercising executive functions[15] but not legislative functions. According to Law Number 30 Year 2014 concerning Government Administration, government actions are limited by statutory regulations and general principles of good governance (AUPB). Therefore, a resolution of policy regulations dispute is carried out by assessing the compatibility of the norms of policy regulations with the laws and regulations and / or AUPB.

Dispute resolution through mediation is carried out by a mediator [16]. In a settlement of a disharmony of laws and regulations, the Director General of Laws and Regulations exercises the duty of the "authoritative mediators". This mediator has the authority to settle disputes. Even when the disputing parties fail to reach an agreement then the mediator is capable of deciding settlement to the dispute [17].

Policy regulation dispute is the same as dispute over disharmony of laws and regulations. Therefore, the authoritative mediators model can be adopted in resolving disputes over policy regulations. However, government officials who become mediators are those who understand the rules, the elaboration of regulations, delegation of government authority, and policy regulations, that is, the top government officials or superiors of the officials creating the policy regulations. This superior government official, in addition to having greater power, has the authority to control and evaluate his subordinates, and the authority to make decisions on problems that arise among his subordinate officials. Their subordinate government officials are bound to carry out the higher level government's programs because the creation of policy regulations by government officials below must be consistent with the above government's programs. Consequently, superior government officials can serve as the authoritative mediators in resolution of policy regulatory disputes.

\section{The process of resolving disputes over policy regulation through mediation}

Until now, resolution of policy regulation dispute through mediation has never beenpracticed. This is 
caused by the absence of legislation governing it. Based on the description above, the process of policy regulation dispute resolutionis through the following stages:

a. People (community) file a request for agreement from government officials creating policy regulation to settle disputes over policy regulations through mediation;

b. People (community) file a request for a settlement of dispute over policy regulation through mediation in writing to government officials who are the superiors of government officials creating the policy regulations;

c. The superior official of the policy-creating official as the mediator arranges meetings with all parties together to settle the dispute over the policy regulation through mediation;

d. In the case of mediation, the superior government official invites the disputing parties (citizens and policy makers) to interpret and assess the suitability of the policy regulation with the existing laws and regulations and / or AUPB;

e. The mediator assists the parties to reach an agreement, to be written a peace deed signed by the disputing parties and superior government officials as the mediator;

f. If the parties do not reach an agreement, ultimately the superior government official can decide on a settlement of the policy regulation dispute.

The mediation agreement as outlined in the peace memorandum or mediation decision is final and binding. The parties are bound to take a full responsibility to implement this peace memorandum.

\section{CONCLUSION}

Settlement of policy regulation disputes can be done through mediation. A policy regulation dispute is an object of mediation. People or communities whose rights have been violated by policy rules have a right to file a requests for mediation to superior officials of the policy- creating officials. The superior officer who acts as the authoritative mediator arranges meeting with all disputing parties. The mediator assists the parties to interpret and assess the appropriateness of the norms of policy regulations with the norms of legislation and / or AUPB. The results of the mediation are set forth in a peace memorandumto be signed by the parties and the mediator; or a mediation decision by the mediator. The results of this mediation are final and binding. Consequently, the parties must take a full responsibility to implement the peace memorandum or the mediation decision.

\section{REFERENCES}

[1] Supreme Court. Decision of the Supreme Court Number 1P/HUM/2016.

[2] The term Beleidsregel used in 1982 in the minutes compiled by commisie wetgevingsvraagstukken, although used together with the terms "psudowetgevinf", "bekang makingan van voorgenomen beleid", "algemene belleidsregels". See Abdul Rozak, Hakikat Peraturan Kebijakan, dalam www.negara hukum.com, 2 April 2015., 1.

[3] Safri Nugraha. Administrative Law, (Jakarta: FH UI, 2008), 93.

[4] Bagir Manan dan Kuantana Magmar, Some Indonesian Constitutional Law Issues, (Bandung: Alumni, 1997), 167.

[5] Sibuea,Hotma P. Rule of Law, Regulatory Policy, General Principles of Good Governance, (Jakarta: Erlangga, 2010), 101

[6] Laica Marzuki. "Policy Regulations (Beleidsregel), The Nature And Functions As A Means Of Government Law ", Paper presented at the National Upgrading of Procedural Law and State Administrative Law, at the Faculty of Law of Hasanudin University Ujung Pandang, 1996, 2.

[7] Laica Marzuki. "Policy Regulations (Beleidsregel), The Nature And Functions As A Means Of Government Law ", Paper presented at the National Upgrading of Procedural Law and State Administrative Law, at the Faculty of Law of Hasanudin University Ujung Pandang, 1996, 2-3.

[8] Hotma P. Sibuea. Rule of Law, Regulatory Policy, General Principles of Good Governance. Jakarta: Erlangga, 2010

[9] A. Hamid S. Attamimi. "Law on Legislation and Policy Regulations", Full Service Speech, (Jakarta: Faculty of Law UI, 1993), 12-13.

[10] Van Kreveld which is followed in the Philipus M. Hadjon, Introduction of Administrative Law, (Yogyakarta: Gadjah Mada University Press), 2002, 56. [11] S. Prajudi Atmosudirjo. State Administrative Law, (Jakarta: Ghalia Indonesia, 1982), 103. 
[12] Zainal Arifin Hoesein, Judicial Review in the Supreme Court, Three Decades of Legislation Testing, (Jakarta: RajaGrafindo Persada, 2009), 38-39.

[13] Sri Soemantri, Material Judicial Review in Indonesia. second edition. 1st printing, (Bandung: Alumni, 1997), 6 and 11.

[14] Markus Lukman," Freies Ermessen in the Process of Planning and Implementing City Plans in the Municipality of Pontianak", Tesis Magister of Law, (Bandung: Unpad, 1989), 116.

[15] A. Hamid S. Attamimi, "The Role of the Decree of the President of the Republic of Indonesia in the Organization of the Government of the Republic of Indonesia. Doctoral Dissertation, (Jakarta: Faculty of Law UI, 1990), 11.

[16] Susanti Adi Nugrono, Mediation as an Alternative Dispute Resolution, second printing, (Tangerang: PT. Telaga Ilmu Indonesia, 2011), 24.

[17] Susanti Adi Nugrono, Mediation as an Alternative Dispute Resolution, second printing, (Tangerang: PT. Telaga Ilmu Indonesia, 2011), 26. 